\title{
Реликты традиций скифского времени в погребальных обрядах тувинцев
}

\author{
Олег Б. Бубенок \\ Институт востоковедения им. А. Е. Крымского Национальной академии наук Украины, \\ Украина
}

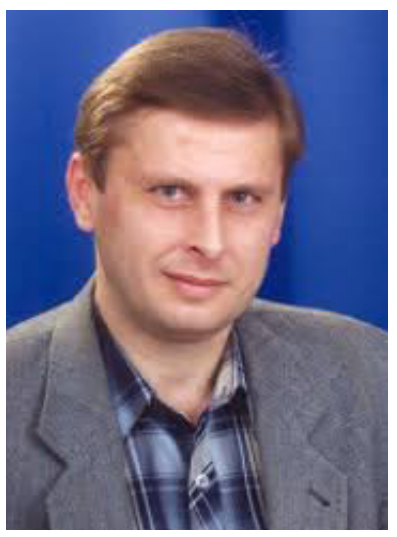

Целью статьи является определение генезиса тех погребальных обрядов тувинцев, которые совпадают с описанием аналогичных традиций у древних скифов. Для сравнительного анализа впервые привлечены этнографические и археологические материалы с территорий не только близлежащих, но и значительно удаленных от Тувы.

Удалось установить, что погребальный обряд курганов скифского времени в Туве (Аржан-1 и Аржан-2) и на Алтае во многом похож на описанные Геродотом похороны у скифов, но не идентичен им. В средние века у тюркоязычных кочевников Центральной Азии, включая земли Тувы, продолжали бытовать «скифские» похоронные обряды. Даже в погребальных ритуалах тувинщев XVII-XX вв., хорошо изученных этнографами, продолжали сохраняться реликты древних традиций.

Древними элементами в традиционной похоронной цееремонии тувинцев, уходящзии своими корнями в доскифскую и скифскую эпохи, можно назвать: ритуальное оплакивание умершего; доставка покойного на деревянных санях или верхом на лошади; захоронение умершего в скорченном положении на боку; под голову покойнику клали подушку; обсыпание умершего зернами проса; деревянные конструкции внутри могилы; захоронение коня; сооружение кургана из камней; изготовление манекена или каменной стелы для изображения погребённого; после похорон поминальная трапеза и ритуальное очищение, и т. п. Вполне возможно, что к тувинцам эти традиции могли попасть от скифов через посредство древних хуннских и тюркских племен.

Делается вывод, что с древнейших времен территория Тувы входила в ареал формирования общей идеологии кочевников Евразии, связанной с погребальным культом. Именно консервативность кочевого образа жизни способствовала тому, что многие древние погребальные традиции смогли сохраниться у тувинцев вплоть до конца ХХ в.

Ключевые слова: тувинцы; Тува; погребальный обряд; похоронная церемония; погребальный культ; скифская эпоха; Аржан-1; Аржан-2; шаманист

\section{Для цитирования:}

Бубенок О. Б. Реликты традиций скифского времени в погребальных обрядах тувинцев // Новые исследования Тувы. 2021, № 1. С. 131-147. DOI: https://www.doi.org/10.25178/nit.2021.1.7

Бубенок Олег Борисович - доктор исторических наук, профессор, заведующий отделом Евразийской степи Института востоковедения им. А. Е. Крымского Национальной академии наук Украины. Адрес: 01001 Украина, г. Киев, ул. Грушевского, д. 4. Тел.: +380674238299. E-mail: helgebub@gmail.com

BUBENOK, Oleg Borisovich, Doctor of History, Professor, Head of the Eurasian Steppe Department, A. Yu. Krymsky Institute of Oriental Studies of the National Academy of Sciences of Ukraine. Postal address: 4, Grushevsky Street, 01001 Kiev, Ukraine. Tel.: +380674238299.E-mail: helgebub@gmail.com 


\title{
Relics of the Traditions of the Scythian Time in Burial Rites of the Tuvans
}

\author{
Oleg B. Bubenok \\ A. Yu. Krymsky Institute of Oriental Studies of the National Academy of Sciences of Ukraine, \\ Ukraine
}

\begin{abstract}
This article aims to determine the origin of those of the Tuvan burial rites which are similar to ancient Scythian traditions. For a comparative analysis, the author of this article used the ethnographic and archaeological materials from territories both adjacent to and distant from Tuva.

The author identified that the funeral rite of the Scythian barrows in Tuva (Arzhan I and Arzhan II), and also of those in the Altai, is similar (but not identical) in many details to the funeral ceremony of the Scythians as described by Herodotus. In the Middle Ages, the Turkic nomads of Central Asia, including the lands of Tuva, continued to have "Scythian" funeral rites. Vestiges of ancient traditions survived even in the burial rituals of shamanist Tuvans in the 17th - 20th centuries.

These ancient elements included the following: ritual mourning for the dead; delivery of the corpse on a wooden sleigh or on horseback to the burial place; burial of the deceased in a crouched position lying on their side; a pillow placed underneath the head; sprinkling the corpse with millet grains; wooden structures inside the grave; burial of a horse; in the recent past - erecting a mound of stones; making a mannequin or a stone stele in the image of the deceased; a memorial feast and ritual cleansing after the funeral ceremony, etc. These traditions could have made their way to the Tuvans from the Scythians through the ancient Hunnic and Turkic tribes.

Thus, we can see that since ancient times, the territory of Tuva was part of the area where Eurasian nomads developed their belief system, including the funeral cult. The conservatism of the nomadic way of life could help preserve many ancient burial traditions among the Tuvans until the end of the 20th century.
\end{abstract}

Keywords: Tuvans, Tuva; funeral rite; funeral ceremony; funeral cult; Scythian era; Arzhan I; Arzhan II; shamanist

For citation:

Bubenok O. B. Relics of the Traditions of the Scythian Time in Burial Rites of the Tuvans. New Research of Tuva, 2021, no. 1, pp. 131-147. (In Russ.). DOI: https://www.doi.org/10.25178/nit.2021.1.7

\section{Введение}

Погребальный обряд тувинцев представляет несомненный интерес для исследователей, ибо в похоронных традициях этого народа наблюдается не только влияние буддизма, но и языческих верований, которые отличаются особым консерватизмом. Не случайно традиционная культура тувинцев стала объектом исследований этнографов, археологов и фольклористов (Катанов, 1894: 128-130; Яковлев, 1900; Кон, 1936; Маннай-оол, 2004, 2010; Дьяконова, 1966: 56-80; 1975; Кенин-Лопсан, 1987: 77-88; Кисель, 2009а: 140-147; 2009b, 2010; Айыжы, 2017 и др.). Они неоднократно обращали внимание на то, что эти традиции уходят корнями в далёкое прошлое.

Так, В. П. Дьяконова одной из первых отметила, что подкурганные и впускные погребения тувинцев XVII-XIX вв. довольно часто содержали сопроводительные захоронения лошадей. В. П. Дьяконова видела в этом прямое заимствование от древних тюрков-тугю. Однако исследователь отметила отличия тувинского варианта: преимущественно впускной характер захоронений, отсутствие четко выраженных могильных ям, разнообразие в ориентировке погребенных, отказ от использования колод и гробов, размещение конского снаряжения отдельно от трупа лошади (Дьяконова, 1975: 151-156). Впоследствии археологические исследования в Туве, связанные с раскопками богатых погребальных курганных комплексов Аржан-1 и Аржан-2, позволили выявить истоки некоторых погребальных традиций тувинцев уже в скифской эпохе. На это одним из первых обратили внимание С. И. Вайнштейн и М. Б. Кенин-Лопсан. Так, М. Б. Кенин-Лопсан в своей монографии «Обрядовая практика и фольклор тувинского шаманства. Конец XIX - начало XX в.» особо выделил следующие элементы обряда захоронения тувинского шамана: под голову клали вместо подушки камень; самого умершего укладывали на правый бок головой на Запад (Кенин-Лопсан, 1987: 88). Исследователь 
поддержал мнение С. И. Вайнштейна, изложенное им в рукописи докторской диссертации еще в 1969 г. (Вайнштейн, 1969), что такие черты обряда могут восходить к традициям скифской эпохи (КенинЛопсан, 1987: 88).

М. Х. Маннай-оол предпринял попытку сравнительного анализа материальной культуры тувинцев и племен скифского времени. В результате он пришел к выводу, что «в наиболее консервативной области тувинской культуры - прикладном искусстве (резьба по камню и дереву, художественное литье), в некоторых мотивах и деталях орнаментики, традиционного костюма прослеживаются весьма древние истоки, восходящие к культуре местных племен скифского времени» (Маннай-оол, 2004: 35). Это позволило исследователю сделать вывод, что кроме тюркоязычных племен в этногенезе тувинцев принимали участие и другие этноязычные элементы. К ним он отнес племена скифского времени (там же: 142). Один из разделов его монографии так и называется: «Племена Тувы в скифское время (VIII-III вв. до н. э.) и образование этнического ядра тувинского народа» (там же: 21-35).

Что же касается проблемы скифского наследия в погребальных обрядах тувинцев, то следует особо выделить публикации В. А. Киселя. Так, одна из его статей даже называлась «Нетюркские элементы погребального обряда тувинцев» (Кисель, 2009а). В ней исследователь предложил считать наследием скифской эпохи традицию укладывать голову умершего на «подушку» (там же: 144). Данные вопросы были также подняты в монографии В. А. Киселя «Поездка за красной солью. Погребальные обряды Тувы. XVIII - начало XXI в.» (Кисель, 2009b). В ней, кроме уже отмеченной, исследователь выделил и другие традиции, по его мнению, уходящие корнями в далёкое прошлое: сопроводительные захоронения лошадей, установление надмогильных стел, обсыпание захоронения просом и т. п. (там же: 35, 36, 38 , 47-48).

Картина была бы неполной без упоминания обобщающих работ других исследователей, посвященных древнему наследию в погребальных традициях народов Центральной Азии. Так, особо следует выделить статью А. В. Стручковой «Скифо-хуннские компоненты в ритуальных конструкциях и предметах бытового назначения из дерева у тюркоязычных народов Сибири» (Стручкова, 2016). Автор считает пережитком традиций скифского времени использование деревянных конструкций при погребении умершего, что до недавнего времени имело место у многих народов Сибири и Центральной Азии, включая тувинцев. Кроме того, исследователь выделила у тувинцев и их соседей пережитки «скифского звериного стиля», что проявилось, по ее мнению, в стилизации деревянных предметов в виде частей тела лошади (там же: 139-140, 142). Что касается последнего утверждения, то В. А. Кореняко в своей монографии, специально посвященной этой проблеме, опроверг его (Кореняко, 2002: 132-133). В заключительной части работы он отметил: «Сопоставление полнофигурных анималистических изображений двух эпох позволило установить, что между образцами скифо-сибирского звериного стиля и “этнографического” искусства гораздо больше различий, чем черт сходства» (там же: 146). В этом он видит проявление конвергенции, а не преемственности.

Как видим, сравнительный анализ похоронных обрядов тувинцев с данными о погребальных традициях других народов Евразийской степи скифского времени может являться довольно перспективным и заслуживает отдельного исследования.

Поэтому целью статьи является определение генезиса тех погребальных обрядов тувинцев, которые совпадают с описанием аналогичных традиций у древних скифов и других народов зоны Евразийской степи. Это предполагает решение следующих задач: выявление тех погребальных обрядов тувинцев и их соседей, которые действительно находят аналогии у скифов; объяснение символического смысла этих ритуальных действий; определение путей проникновения этих обрядов в среду тувинцев и их соседей во временном и пространственном контексте и т. п.

В соответствии с перечнем поставленных задач основным является метод этнографических параллелей. Методологической основой работы стали концепции представителей диффузионистского направления в культурной антропологии (Frobenius, 1909; Graebner, 1905), а также идеи историков-евразийцев (Вернадский, 1934; Гумилев 1989). В основу исследования также положена собственная концепция автора статьи о возникновении комплекса погребальных обрядов в древнее время в одном месте и дальнейшем распространении их на просторах Евразии в результате передвижений кочевников (Bubenok, 2002, 2012). Поэтому для проверки правильности этой концепции особое значение имеет привлечение тувинского материала.

Особое внимание автор исследования сосредоточил на таком феномене как «погребальные традиции». Обычно под погребальными традициями подразумевают систему норм и правил поведения 
при захоронении умершего, которые имеют связь с представлениями о загробной жизни и передаются из поколения в поколение. Однако опыт показывает, что довольно часто религия, как идеологическая надстройка, меняется, а похоронные обряды продолжают сохраняться. При этом в новых условиях им придается новое содержание, весьма отличное от первоначального.

Поэтому автор статьи вполне согласен с выводом А. В. Вертиенко: «Запрограммированное традицией воспроизведение обрядов в неизменном виде базируется на вариативности, что обеспечивает возможность приспосабливать тот или иной обряд к конкретным обстоятельствам его проведения или связано с характером (фактором) смерти погребенных... Подобные варианты ни в коем случае не свидетельствуют о результате разрушения традиций, или их забывания, а, наоборот, варьирование является необходимым условием существования обрядовой традиции» (Вертієнко, 2007: 4).

Автор статьи впервые привлек для сравнительного анализа этнографические и археологические материалы, собранные в XX - начале XXI в. на территориях не только близлежащих, но и значительно удаленных от Тувы (Восточная Европа, Северный Кавказ, Средняя Азия), а также данные письменных источников. Это и составляет научную новизну исследования. Новизной и нестандартностью отличается и сама постановка вопроса - скифское наследие в погребально-поминальных традициях тувинцев.

\section{Похоронные обряды кочевников Тувы и Алтая в скифскую эпоху и средневековье}

Проблема скифского наследия в погребальной обрядности очень актуальна для Тувы. В связи с этим следует акцентировать внимание на том, что в Туве М. П. Грязновым был исследован курган Аржан-1, который был частично ограблен. Аржан-1 представлял собой погребальный комплекс, совершенный под каменной кладкой кургана. Это была гробница «царя» с элементами погребального обряда, который был похож на скифский, описанный Геродотом: захоронение «царя» и «царицы» были расположены в центре; вокруг них обнаружены погребения семи старцев и одного юноши с шестью конями; в отдалении от центральной могилы были захоронены еще всадники с лошадьми; общее количество сопровождающих умершего «царя» и его «жену» достигает 15 человек. Рядом с центральной могилой «царя» были захоронены почти 160 коней; в шести срубах с южной и восточной стороны были погребены отдельно по 30 и 15 верховых коней в каждом и три коня отдельно между срубами. М. П. Грязнов датировал курган Аржан VIII-VII вв. до н. э. (Грязнов, 1980: 45-59). Однако Л. Р. Кызласов датировал курган Аржан VII-VI вв. до н. э. (Кызласов, 1979: 35-41). По мнению авторов коллективной монографии «Евразия в скифскую эпоху: радиоуглеродная и археологическая хронология», курган Аржан корректней датировать «приблизительно 800 г. до н. э.» (Евразия в скифскую ..., 2005: 215).

Спустя некоторое время был исследован погребальный обряд находящегося недалеко кургана Аржан-2, раскопки которого проводились в 1998-2003 гг. Как оказалось, курган не был ограблен. Под каменной насыпью были обнаружены 10 основных захоронений и несколько впускных могил. Центральным оказалось неограбленное погребение № 5 или могила «царя» и женщины в погребальной камере с двойными стенами из бревен. Головы погребенных, по мнению исследователей памятника, первоначально находились на подушках из органического материала. Погребенные лежали на левом боку в слегка скорченном положении головами на северо-запад. Около юго-восточной стенки камеры находилось захоронение маленького ребенка в колоде. Кроме того, были обнаружены сопутствующие захоронения мужчин и женщин в каменных ящиках в скорченном положении на левом боку головой на северо-запад (погр. №№ 7, 12, 22, 24, 25, 26, 14, 22, 11). Открыты 16 конских захоронений в ямах, перекрытых плитами или бревнами. Под плитами каменного вала кургана были найдены 4 клада с предметами конского снаряжения. Кроме того, в каменной кладке кургана находились 26 впускные захоронения людей (могилы №№ 1-6, 15-19, 21, 23, 27-29) (Чугунов, Парцингер, Наглер, 2017: 27-126). Исследователи этого памятника отнесли сооружение царской могилы кургана Аржан-2 ко второй половине VII в. до н. э. (там же: 179). К. В. Чугунов выделил общие черты в погребальном обряде комплексов Аржан-1 и Аржан-2, что позволило ему сделать вывод об их генетической связи (Чугунов, 2009: 179-185). Однако захоронения царей скифского времени в Туве не единственные в Центральной Азии.

Именно благодаря вечной мерзлоте сохранились захоронения кочевников скифского времени на Алтае, что помогло в деталях реконструировать погребальную церемонию в Пазырыкских курганах. Так, удалось установить, что погребальные традиции на Пазырыкских и причерноморских скифских курганах, а также в Туве, имели много общего. Исследователь памятника С. И. Руденко продатировал Пазырыкские курганы Алтая V-IV вв. до н. э. (Руденко, 1953: 62-69, 326-361). Однако авторы кол- 
лективной монографии «Евразия в скифскую эпоху....» датируют «курганы 1 и 2 могильника Пазырык 325-272 гг. до н. э.», а «курган 5 могильника Пазырык - приблизительно 250 г. до н. э.» (Евразия в скифскую ..., 2005: 215).

Погребальный обряд курганов скифского времени в Туве и на Алтае во многом похож на описанные Геродотом похороны у скифов, но не идентичен им. Геродот оставил нам довольно детальные сведения о погребальной церемонии как скифских царей, так и других скифов в «Истории греко-персидских войн» (Иванчик, 2010: 144; Геродот, 1972: 205).

Несмотря на значительный промежуток времени, у ранних тюркоязычных кочевников «скифские» погребальные обряды продолжали бытовать длительное время. Так, уже давно среди исследователей латиноязычного сочинения Иордана «О происхождении и деяниях гетов» (Getica) вызывает большой интерес описание похорон гуннского вождя Аттилы (Иордан, 1960: 117-118). При анализе обряда погребения Аттилы Л. А. Гиндин и Ф. В. Шелов-Коведяев отметили, что погребальные традиции гуннов очень напоминают похоронные обычаи скифов (Гиндин, Шелов-Коведяев, 1994: 168). Не меньший интерес может представлять аналогичная погребальная церемония дагестанских гуннов в VII в., описанная Мовсэсом Каланкатуаци в «Истории Албании» (Мовсэс, 1984: 124).

Следует акцентировать внимание на том, что гунны в первые века нашей эры двинулись в Европу из Центральной Азии. В то же время в степях Центральной Азии в раннее средневековье в погребальной церемонии местных кочевых племен продолжали сохраняться традиции скифского времени, но тогда же здесь появились новации. Так, аналогичная погребальная обрядность была зафиксирована у древних тюрок. Китайская хроника «Тань-шу» в погребальной церемонии тюрок-тугю в начале VII в. н. э. отмечает немало общего с обычаями скифов, но при этом восточные тюрки вместо захоронения по обряду ингумации стали практиковать кремацию (Бичурин, 1950: 230).

Для сравнительного анализа следует отметить, что уже давно в этнографической литературе было акцентировано внимание на том, что значительное количество элементов погребального обряда древних кочевников Евразии сохранилось в похоронных традициях осетин. Этнографы выделили черты в их похоронной церемонии, которые очень напоминают скифские. Это исследователи объясняют генетическими связями этого народа с племенами скифо-сармато-аланского круга, которые периодически мигрировали через степи Северного Кавказа, где и задерживались (Калоев, 1984: $72-$ 105; Дюмезиль, 1990: 188-198; Бесолова, 2007).

В данном случае ничто не мешает предполагать, что аналогичные погребальные традиции у кочевников Центральной Азии также могут восходить к скифскому времени. В эпоху средневековья на территории Тувы происходили довольно частые изменения в составе населения, что было связано с политическим событиями. Менялся и погребальный обряд населения Тувы. Однако следует отметить одну особенность: со времен Первого Тюркского каната и до Монгольской империи на территории Тувы проживало население, которое продолжало хоронить умерших по обряду ингумации в сопровождении коня под каменными курганными насыпями (Кызласов, 1969: 18-44, 65-80, 97-114). Как видим, на территории Тувы с древних времен и до конца средневековья продолжала сохраняться преемственность в погребальных традициях.

\section{Пережитки древних традиций в погребальных обрядах тувинцев в XVII-XIX вв.}

Казалось бы, вряд ли могла сохраниться прямая преемственность между погребальными обрядами кочевников Центральной Азии скифского времени и похоронными традициями современного народатувинцев. Однако уже предварительный анализ показывает, что некоторые черты погребальной церемонии тувинцев-шаманистов находят определённое сходство с погребально-поминальными обрядами скифов, описанными Геродотом, и родственных им осетин, а также с погребальной церемонией, зафиксированной на курганах скифского времени Аржан-1 и Аржан-2.

Исследователи уже давно акцентировали внимание на том, что у тувинцев существали две погребальные традиции, связанные с бытованием религий - шаманистской и буддистской. Приверженцы первой традиции сохранили немало от давних времен (Дьяконова, 1975: 5). В тувинском фольклоре зафиксированы четыре варианта похорон: ингумация, кремация, надземные («воздушные») погребения, оставление трупа на поверхности земли (Дьяконова, 1974: 262-263; Курбатский, 2001: 149). Это подтвердили и исследования этнографов. Согласно предложенной В. А. Киселем типологии, до начала XX в. тувинские погребения делились на подземные, наземные и надземные типы (Кисель, 2009b: 22-24). 
Следует отметить, что В. П. Дьяконова начала изучение эволюции погребального обряда тувинцев с памятников материальной культуры, датируемых XVII-XIX вв. Эти поздние археологические объекты дали информацию, которая уже не доступна этнографии. Первое, что бросается в глаза, это наличие у тувинцев каменных курганов (Дьяконова, 1975: 17). Как будет далее отмечено, в XX в. тувинцы уже не сооружали курганную насыпь над могилой. Но каменные насыпи имели курганы Аржан-1 и Аржан-2 (Грязнов, 1980: 45-59; Чугунов, Парцингер, Наглер, 2017: 302-303). Кроме того, Пазырыкские курганы скифского времени на Алтае также имели каменные насыпи (Руденко, 1953: 25, 39). Каменные курганы на территории Тувы имели сложную конструкцию. Кроме того, в Туве в скифское время наряду с каменными курганами сооружались каменно-земляные и земляные (Грач, 1980: 69-70). Как уже отмечалось, со времен Первого Тюркского каганата и до Монгольской империи на территории Тувы проживало население, которое продолжало хоронить умерших по обряду ингумации с конем под каменными курганными насыпями (Кызласов, 1969: 18-44, 65-80, 97-114). В Туве в XVII-XIX вв. подкурганные погребения были как основные, так и впускные в каменную насыпь древних курганов.

В контексте идей преемственности традиций необходимо остановиться на функциональном назначении как каменных, так и земляных курганных насыпей. Иногда для объяснения понятия курган приводят тюркский термин Qurǵon - «сооружение, крепость». Но курганы появились в степях Евразии задолго до расселения тюркских племен. Поэтому возможна и другая семантика слова. Так, еще в середине XX в. известный украинский востоковед А. П. Ковалевский высказал предположение, что слово курган имеет древнеиранское (скифское) происхождение. По его мнению, в этом слове следует видеть составной термин «могила-дом» (ср. перс. гур-хане) (Ковалівський, 1995-1996: 148). Таким образом, земляное или каменное сооружение, по замыслу древних кочевников, должно было символизировать посмертное жилище умершего. Однако возникает вопрос: почему тувинцы не сооружали земляных насыпей? Ведь так было проще. Это можно объяснить лишь тем, что сооружению именно из камня придавались особые функции в контексте представлений о загробной жизни. Очевидно, не случайно совершались впускные захоронения в каменные насыпи древних и средневековых курганов. Поэтому вполне возможно сохранение у тувинцев представлений, уходящих своими корнями в скифскую эпоху.

Под всеми погребенными в курганах XVII-XIX вв. были обнаружены покрытия из дерева, бересты и т. п., а также сопровождающий инвентарь и остатки в ряде случаев баранов и лошадей. Особенно показателен в этом отношении курган Кок Ховаг І. Здесь были два погребения - мужчины и женщины в скорченном положении на боку, а также захоронение коня. Все как в курганах скифской эпохи. Но парное захоронение для Тувы тех времен - уже большая редкость (Дьяконова, 1975: 17).

Особо следует остановиться на обряде захоронення в скорченном положении на боку. Как известно, в скифское время в азиатской части степной Евразии предпочитали укладывать покойного скорченно на боку, а в европейской - в вытянутом положении на спине. «Скорченные» захоронения имеют широкое распространение в Евразии и уходят своими корнями во времена позднего палеолита, т. е. они появились задолго до начала скифской эпохи (Грач, 1980: 70). И в этом нет ничего необычного, ибо эмбриональная поза умершего, по одной из версий, могла символизировать перерождение для начала новой жизни в потустороннем мире.

Кроме Тувы, «скорченные» погребения на боку догуннской эпохи были зафиксированы в Восточной Европе под курганными насыпями в степном Поднепровье (Савовський, 1977: 62, 65), в бассейне Северского Донца (Трефильев, 1905: 134-135). Они были представлены как мужскими, так и женскими захоронениями. По наблюдениям А. П. Моци, отдельные «скорченные» погребения как мужчин, так и женщин в первой половине I тыс. н. э. были известны среди носителей черняховской культуры, а в раннее средневековье - среди салтовского населения, среди протоболгар и жителей Скандинавии. В более же позднее время они встречались в ряде мест Древней Руси (Моця, 1987: 101-104). Как видим, этот обряд универсален для народов Евразии, но его сохранение в позднее время именно на территории Тувы может быть связано с традициями местного населения скифской эпохи.

Следует обратить особое внимание на традицию погребать умершего с конем. Богатые захоронения с более чем 160 конями были обнаружены в Туве уже в кургане Аржан-1 (Грязнов, 1980:45-59). В кургане Аржан-2 найдены останки более 16 коней и клады с конским снаряжением (Чугунов, Парцингер, Наглер, 2017: 99-119). Погребения с конем были также представлены на Пазырыкских курганах скифской эпохи на Алтае. Они встречались как в курганах знати, так и в могилах простых кочевников (Руденко, 1953: 23, 40-43, 56-60, 71-72, 332). Следует отметить, что в скифское время коней погребали и в курганах Северного Причерноморья. Особый интерес могут представлять недавние выводы М. ОчирГоряевой относительно причин распространения сопровождающих конских захоронений скифского времени в курганах Северного Причерноморья: 
«В погребальных сооружениях скифов конские погребения занимали место дорогого сопровождающего погребального “инвентаря”, соответствующего статусу важных транспортных животных. В отличие от других транспортных животных - волов и верблюдов, которые также использовались в хозяйстве кочевников, - кони были показателем социального престижа. Роскошные уздечные наборы соответствовали высокому статусу, но не самих коней, а погребенного в этом кургане человека - их “хозяина” (Очир-Горяева, 2017: 107).

Что же касается идеологического контекста, то Е. Е. Кузьмина в свое время охарактеризовала смысл жертвоприношений коня у народов древности следующим образом:

«Роль коня в этих ритуалах состоит в том, что конь выступает, прежде всего, как посредник между миром живых и небесной обителью. ... То же самое имеют и скачки, устраиваемые на поминках.... Однако, по-видимому, конь в погребальном ритуале играет не только посредническую роль. Значение коня состоит в том, что он является силой, способной обеспечить человеку возрождение к новой бессмертной жизни на том свете» (Кузьмина, 1977: 41).

По наблюдениям исследователя, культ коня возник у племен степей Евразии еще в эпоху энеолита и получил дальнейшее развитие у племен скифской и более поздних эпох. Имел распространение он и среди кочевников тюрко-монгольского мира (там же: 29-30, 42-45).

Однако в Туве в скифское время вместе с умершими, за исключением «царственных» особ, как правило, не хоронили убитых коней. Их заменяла узда (Грач, 1980: 73-74). В то же время на Алтае, как уже отмечалось, кони встречались как в курганах знати, так и в захоронениях простых кочевников (Руденко, 1953: 23, 40-43, 56-60, 71-72, 332). По данным А. Д. Грача, сопроводительные погребения коней были обнаружены на территории Тувы в кургане № 1 могильника Сагла-Бажи II алтайской пазырыкской культуры (Грач, 1980: 74). Поэтому следует признать, что захоронения с конем у различных племен скифской эпохи могли нести в себе как социальную, так и идеологическую нагрузку. В то же время бытование на территории Тувы со скифских времен и до начала XX в. погребений с конем отнюдь не случайно, ибо культ коня у кочевников является непременным атрибутом их традиционной культуры. Поэтому нельзя дать однозначный ответ на вопрос, являлись ли захоронения с конем на территории Тувы прямым наследием скифской эпохи или нет.

Но вернемся к впускным захоронениям XVII-XIX вв. в курганах Урянхайского края. Эти погребения были одиночными, содержали инвентарь и сопровождались останками коней и баранов. В одном из таких женских захоронений голова женщины покоилась на кожаной подушечке. Весьма характерно, что в более поздних захоронениях тувинцев также довольно часто клали под голову как кожаные, так и каменные подушки (Дьяконова, 1975: 22, 32, 35-36, 68, 76). Исследователи погребального комплекса Аржан-2 считают, что в центральной могиле № 5 у погребенных там мужчины и женщины «первоначально головы лежали на подушках из органического материала» (Чугунов, Парцингер, Наглер, 2017: 32). Археологические раскопки в Туве зафиксировали размещение черепов погребенных на плоском камне или каменной плитке и в других погребальных памятниках скифской эпохи (Грач, 1980: 111-118, 122; Кисель 2009b: 47-48; 2009a: 144). В то же время на Алтае в погребениях скифской эпохи были обнаружены настоящие бытовые вещи - деревянные подголовники с надетыми чехлами из кожи и меха, а также войлочные, кожаные и, возможно, берестяные подушки (Руденко, 1953: 51). На основании этих фактов, В. А. Кисель высказал предположение, что этот «нетипичный тувинский обряд восходил к скифской культуре. Он практиковался в очень ограниченном кругу и имел особое значение» (Кисель, 2009b: 48).

Рядом с одним из впускных захоронений были обнаружены два ручных каменных жернова (Дьяконова, 1975: 26). Эта деталь довольно необычна и требует объяснения. Из современных народов зоны Евразийской степи подобный обычай наблюдается у осетин. У них было принято класть мельничные жернова в могилу последнего мужчины в роду, т. е. это означало, что род прерывался (Калоев, 1984: 86). Однако в данном случае жернова находились рядом с женским захоронением. Следовательно, такое объяснение не подходит.

До конца XIX в. в Туве еще сохранялись захоронения в жилищах. По данным В. П. Дьяконовой, в роли жилищ выступали «небольшой конический шалаш из тонких жердей» и сруб. Этот обряд был зафиксирован исключительно на Юге и Западе Тувы (Дьяконова, 1980: 115). И хотя захоронения в срубе были наземными, не исключено, что их истоки следует искать в подкурганных погребениях скифской эпохи. Следует напомнить, что царские захоронения в курганах Аржан-1 и Аржан-2 были совершены в деревянных срубах, которые должны были символизировать постоянное жилище в потустороннем мире (Грязнов, 1980: 15-21; Чугунов, Парцингер, Наглер, 2017: 27-29). Почти все 
погребения в Пазырыкских курганах также были совершены в деревянных срубах (Руденко, 1953: 26-42). А. В. Стручкова даже считает, что использование дерева при сооружении наземных сооружений для захоронений шаманов у тувинцев, хакасов, якутов и других тюркоязычных народов Сибири является отголоском традиций скифо-хуннских времен (Стручкова, 2016: 140). Однако погребения в срубах в скифскую эпоху совершались под курганными насыпями, а более поздние представляли собой наземные и даже надземные сооружения. Поэтому трудно определить, являлось ли эта особенность продолжением именно скифской погребальной традиции.

Отмеченные здесь традиции представляют большой интерес, ибо насчитывают не одно столетие. Но по понятным причинам они оказались слабо изученными.

\section{Элементы обрядов скифского времени в похоронных обычаях тувинцев XX в.}

Наиболее же изученным оказался погребальный обряд тувинцев в XX в. При этом исследователи особое внимание уделяли носителям шаманистских традиций. Ряд обычаев тувинцев выглядит совершенно противоположным относительно других традиций народов Евразийской степи; например, традиция хоронить умершего не в праздничной, а повседневной одежде (Дьяконова, 1975: 50-51). Однако у соседей тувинцев - шорцев перед погребением тело умершего обмывали, переодевали в чистую рубаху и штаны и перекладывали в гроб (Кимеев, 2009: 120). Аналогичным образом поступали и хакасы (Бурнаков, 2009: 129). Хотя не исключено, что это является следствием влияния русских. Из современных народов зоны Евразийской степи подобная традиция хорошо представлена у осетин. Считалось, что так умерший должен предстать в День суда (Калоев, 1984: 77). То, что этот обычай древний, подтверждают богатые находки в курганах скифской эпохи, где умершие были погребены в наилучших своих одеждах. Отсутствие именно этой традиции у тувинцев удивляет и является следствием их недавних идеологических воззрений.

В то же время есть у тувинцев традиции, известные среди других народов Евразии. Так, иногда в начале похорон делали из теста изображение умершего и потом его сжигали. Это этнографы объясняли страхом перед духом умершего, который должен был уйти (Дьяконова, 1975: 50-51). Подобная традиция сохранялась у некоторых тюркоязычных и ираноязычных народов (Каховский, 1965: 190; Дюмезиль, 1990: 189; Калоев, 1984: 94; Рапопорт, 1971: 86-89).

Одним из очень древних обычаев следует считать оплакивание умершего. Однако у тувинцев оплакивание имело специфические черты. Так, умершего в основном оплакивали женщины. Считается, что оплакивание представляет собой одну из предохранительных мер от умершего (Дьяконова, 1975: 53-54). По данным Б. А. Калоева, в Осетии «в древние времена в оплакивании принимали участие все присутствующие. При этом мужчины, входя парами к покойнику, били себя плетями по голове и шее» (Калоев, 2004: 328), а женщины рыдали, рвали на себе волосы и расцарапывали в кровь лицо. В былые времена в каждом селении были профессиональные плакальщицы (там же: 327-328). Уже ближе к нашему времени у осетин оплакивать умершего в основном стали женщины (Калоев, 1984: 74-75). Эти традиции очень напоминают скифские, описанные Геродотом (Иванчик, 2010: 144; Геродот, 1972: 205). Однако у тувинцев оплакивание не сопровождается сценами самоистязания участников похоронной процессии, что мы наблюдаем у кочевников скифской, хуннской и раннетюркской эпох (Иванчик, 2010: 144; Иордан, 1960: 117-118; Бичурин, 1950: 230).

Тувинцы довольно часто везли покойника к месту погребения на лошади. Известно несколько способов такой транспортировки. Так, покойника доставляли на верховой лошади, перекинутым через седло. При этом сзади седла сидел сопровождающий. В районе Монгун-Тайги умершего везли на тасках (специальных жердях для транспортировки груза, которые привязывались к лошади и были похожи на носилки). Иногда умершего даже усаживали на седло верховой лошади и везли в сидячем положении до места погребения. У тувинцев женщину везли верхом к месту погребения лишь в том случае, если у нее была лошадь и седло (Дьяконова, 1975: 54-55).

М.А. Очир-Горяева зафиксировала обычай транспортировки умершего в седле в сидячем положении верхом на лошади не только среди тувинцев, но и других кочевых народов: калмыков, алтайцев и др. Кроме того, исследователь считает, что подобный обычай транспортировки знатных умерших существовал у древних кочевников, свидетельством чего является особая поза погребенных в богатых курганах скифской и сарматской эпох: умершие лежали вытянуто на спине с широко расставленными ногами (Очир-Горяева, 2019). 
Кроме того, в Эрзинском районе, у тувинцев еще везли умерших в любое время не только при помощи волокуши из жердей, но и на деревянных санях (шанак), которые привязывали длинными веревками к седлу верховой лошади. Один родственник вел эту лошадь, взяв под узды, не садясь в седло (Дьяконова, 1975: 55). Весьма характерно, что такой же обычай сохранялся у осетин. По данным этнографов, в Южной Осетии везли умершего к кладбищу на санях в любое время года (Калоев, 1984: 92). Этот обычай зафиксирован и среди восточных славян. Так, около ста лет назад Д. К. Зеленин об этом сообщал: «В старину покойников даже летом везли па кладбище в санях: по-видимому, для этого избирали именно сани как древнейший вид повозки. В Олонецкой губ. этот обычай существовал еще недавно...» (Зеленин, 1991: 350). В связи с этим, следует отметить, что для народов Евразии данный обычай универсален. В то же время можно полностью согласиться с Д. К. Зелениным, что сани представляют собой «древнейший вид повозки», который предшествовал появлению транспортных средств на колесах. Поэтому вполне возможно, что данный тип транспортировки покойного возник в степях Евразии в доскифское время, продолжал существовать в скифское время и дожил до наших дней в виде реликта у тувинцев и осетин. Очевидно, у тувинцев таким же древним видом транспортировки умершего является перевозка тела на тасках - специальных жердях для транспортировки груза, которые привязывались к лошади (Дьяконова, 1975: 54-55). В связи с этим, можно вспомнить индейцев Северной Америки, которые не знали до прихода европейцев колеса и поэтому использовали волокуши, представлявшие собой также две жерди, которые привязывались различными способами сначала к собакам, а потом к лошадям

Уже в XX в. тувинцы не сооружали над могилой курганов. Они просто выкапывали яму глубиною около 2 м и клали рядом в могиле снятую с умершего одежду. Из древних традиций у тувинцев сохранялся обычай погребения с животными, которых убивали непосредственно перед захоронением. С мужчинами еще продолжали хоронить коней, а с женщинами - овец (там же: 56). Характерно, что в течение XX в. у тувинцев уже перестали погребать умершего с конем. Однако в Сут-Хольском районе сохранялся пережиток этой традиции - иногда при завершении похорон у могилы на некоторое время оставляли лошадь, на которой везли умершего (там же: 57). Кроме того, в Эрзинском районе, после похорон умершего участники похоронной процессии три раза объезжали по ходу солнца на лошадях вокруг могилы. При этом старший родственник еще бросал на это место зерна пшеницы и ячменя (там же: 57). Подобный обычай посвящения коня умершему существовал у осетин. Он был подробно описан Б. А. Калоевым. По его данным, у осетин перед погребением коня наряжали и ставили у изголовья умершего. После произнесения речи в честь посвящения коня умершему старик-посвятитель отрезал у коня кончик уха, часть гривы, разбивал сосуд с напитком о копыто коня и обводил коня трижды вокруг покойника. Уже после этого происходило само погребение (Калоев, 1964: 2-3). Этнографы единодушны во мнении, что подобные обычаи являются замещением жертвоприношения коня изза чисто экономических соображений, ибо конь представлял большую ценность для родственников умершего. Таким образом, здесь можно говорить о конвергенции обряда у различных народов, а не о заимствовании из общего источника.

В. П. Дьяконова сообщает, что богатому покойнику, как мужчине, так и женщине, недалеко от могилы ставили каменную стелу либо у изголовья, либо у ног покойного. При этом стела стояла среди камней, установленных у могилы по числу детей покойного. Считается, что такая стела изображала умершего (Дьяконова, 1975: 56). Стоит отметить, что такой же обычай существовал у древних тюрок (Бичурин, 1950: 230). Кроме того, в Южной и Юго-Восточной Туве при погребении или поминках из одежды умершего сооружали макет-куклу, который условно изображал сидящего человека (Дьяконова, 1975: 74; 1980: 115; Кисель, 2009b: 17). В связи с этим возникает вопрос не только о генезисе данной традиции, но и первоначальном функциональном её назначении. Данные этнографии и археологии позволяют в определенной мере решить этот вопрос.

Описанный обычай имел широкое распространение у других тюркоязычных народов. Так, у мрасских шорцев шаман закапывал рядом с надмогильным холмом специально вырезанную из кедра куклу - вместилище для души сюне (Кимеев, 2009: 121). У чувашей накануне поминок изготавливали из дерева фигуру человека, которая называлась юпа. Считалось, что она должна была символизировать умершего и в нее временно должна была вселиться душа покойника. Поэтому эту статую вносили в жилище и одевали на неё вещи покойного. Возле чучела ставили стол с пищей и напитками, часть

${ }^{1}$ Следует отметить, что современные исследователи уже поднимали вопрос о совпадениях в конструкциях волокуш Южной Сибири и Северной Америки в контексте проблемы контактов населения двух материков (Окладникова, 1988: 101-110; Окладников и др., 1979: 103, табл. 62). Однако это тема не является предметом настоящего исследования. 
из которых посвящалась умершему. На следующее утро юпа вывозили на кладбище и устанавливали у изголовья погребенного (Каховский, 1965: 190).

Характерно, что изготовлением «заместителя умершего» занимались многие народы, в том числе и оседлые. Этой традиции была посвящена специальная статья Б. П. Шишло. По наблюдениям исследователя, в Средней Азии у тюркоязычных народов такой заместитель назывался тул. На основе данных о распространении такого явления, как «заместитель умершего» лишь у тюркоязычных народов Евразии и некоторых народов Сибири Б. П. Шишло высказался в пользу того, что данная ритуальная практика была универсальна для всех народов (Шишло, 1975: 248-260).

Однако Б. А. Калоев придерживался другого мнения на этот счет. Он считал, что данный обычай попал к тюркоязычным народам и этносам, проживавшим на границе с Евразийской степью, от предшествовавшего ираноязычного населения Евразии (Калоев, 1984: 94). Доказательство этого он видел в терракотовых статуэтках, найденных на территории древнего Хорезма, которые должны были изображать умершего (Рапопорт, 1971: 86-89). Другим доказательством данной гипотезы стало распространение этой традиции у современных осетин.

У осетин подобная традиция имела место под Новый год и имела название «Ночь мертвых». Осетины считали, что душа умершего в это время вселялась в чучело, которое изображало умершего. Чучело представляло собой крестообразные палки, на которые одевали костюм умершего. Его устанавливали на видном месте, перед богато накрытым столом. Рядом раскладывали любимые вещи покойного. Перед чучелом ставили чашку и бутылку араки, предназначенные для поминаемого. В течение дня происходило оплакивание, а затем угощение (Дюмезиль, 1990: 189; Калоев, 1984: 94). У многих народов зоны Евразийской степи существовал подобный обычай. В результате мы видим данную традицию как у тюркоязычных, так и ираноязычных народов, чье прошлое было связано со Степью.

Получается, что сооружаемые на средневековых курганах антропоморфные стелы (так называемые «каменные бабы»), могли символизировать умершего, душа которого во время поминок должна была вселяться в изображение умершего. Необходимо учитывать, что поминки у кочевников могли совершаться именно в тот период, когда маршруты их передвижений проходили вблизи от курганной могилы. Возникает вопрос: насколько древним является этот обычай? У Геродота нет прямых указаний на этот счет, ибо он не упоминает о сооружении на курганах стел (Иванчик, 2010: 144). Однако в скифское время в VI-III в. до н. э. в северопричерноморских степях на курганах уже устанавливали антропоморфные каменные изваяния (Хазанов, 1975: 88; Молев, Молева 2013: 15-21). Но если углубиться еще дальше, то данную традицию можно обнаружить еще в памятниках эпохи меди-бронзы.

В могиле тувинцы степных и лесостепных районов Тувы, а также Монголии обсыпали покойного и само место погребения зернами проса (тараа). По мнению этнографов, это символизировало пожелание «возрождения нового, многочисленного поколения» (Даржа, 2007: 162; Кисель, 2009b: 28; Айыжы, 2017: 78). Как оказывается, эта традиция восходит к древнему времени. Некоторые исследователи считают, что древнетюркским или даже хуннским наследием является ритуал обсыпания захоронения просом. По их мнению, это подтверждается присутствием в древних погребальных памятниках скоплений полуистлевших зерен (Вайнштейн, 1972: 156; Дьяконова, 1975: 132-133; Кисель, 2009b: 38). Был известен подобный обычай и в скифское время на Алтае. В связи с этим С. И. Руденко отметил:

«Основным занятием древних горноалтайцев было скотоводство. Земледелием они не занимались, и в их погребениях в незначительном количестве были найдены только зёрна проса и дикорастущей конопли. Зерна эфирномасличного посевного кориандра, обнаруженные почти во всех курганах, были несомненно привозными с юга» (Руденко, 1968: 18).

В данном случае нельзя игнорировать присутствие зерён проса и других растений в погребениях алтайцев скифского времени. Не исключено, что данный обряд имел довольно прозаическое назначение: покойному предоставлялось то, что было необходимо ему в загробной жизни - зёрна проса и дикорастущей конопли. Как известно, просо являлось чуть ли ни единственной зерновой культурой, которую выращивали кочевники. Поэтому появление зерён проса в погребениях кочевников хуннского и древнетюркского времени могло иметь то же назначение. У близких к современности тувинцев сохранилась эта древняя традиция, но, как это часто бывает, древний обычай наполнился новым содержанием. Поэтому пока проблематично говорить о том, что данный обычай мог попасть $\mathrm{K}$ тувинцам именно от скифов через посредство древних тюркских племен.

После похорон у тувинцев следовало ритуальное очищение - участники процессии мыли руки и лицо водой, взятой из родника и разбавленной молоком, а также окуривали себя и место поминаль- 
ной трапезы можевельником (Дьяконова, 1975: 59). У тувинцев Монголии этот обряд имел еще более архаические черты. Е. А. Айыжы сообщает: «Вернувшись с похорон, все участники проходят обряд “очищения”, для чего готовят два сана - два плоских камня, поверх которых для очищения кладут зажженный можжевельник, воду, разбавленную молоком и можжевельником, белое полотенце или бумагу для вытирания рук. Каждый должен пройти между двумя камнями с можжевельником, затем два раза моют руки и вытираются белым полотенцем» (Айыжы, 2017: 78). Считается, что такое очищение было необходимо, чтобы умерший не вернулся за теми, кто его хоронил. Хотя могут быть и другие объяснения этого обычая.

Не исключено, что корни данных обычаев могут восходить к скифскому времени. Вспомним скифскую паровую баню, описанную Геродотом. Как известно, древнегреческий историк описал ритуальное очищение после похорон простого скифа в своеобразной паровой бане, которая представляла собой специальный шалаш, изнутри обкуриваемый коноплей, которую бросали на раскаленные камни. В такой бане скифы не только сильно потели, но и приходили в транс (Геродот, 1972: 205). Напомним также, что в Пазырыкских курганах были найдены специальные котлы с камнями и коноплей для ритуального очищения, что совпадает с описанием Геродота скифских обычаев (Руденко, 1953: 62-69, 326-361).

Следует обратить внимания на то, что в обоих случаях представлены различные представители флоры: у тувинцев, как и у большинства тюркских народов, - ветки можжевельника; у скифов семена конопли. При этом тувинцы совершают обряд на открытом воздухе, а скифы - в своеобразном шалаше. Поэтому может сложиться впечатление, что цели ритуалов тоже не совпадали: задачей тувинцев было пропитаться запахом дыма, чтобы отпугнуть вредоносных духов; у скифов - войти в транс для общения с потусторонними силами.

Однако Геродот весь этот процесс у скифов не называет ритуальным действием, а использует для его обозначения слово «баня» (Геродот, 1972: 205). Эту паровую «баню» Геродот считает изобретением скифов, так как «водой они вовсе не моются» (там же). Он даже сравнивает скифскую «баню» с эллинской. Подобные паровые бани в шалаше или палатке повсеместно были распространены у многих народов, которые вели подвижный кочевой образ жизни. И бросание семян конопли на раскаленные камни из описания Геродота предстает как нечто вторичное, что заставляет считать скифскую паровую баню первичной. Следует отметить, что в религиозной практике многих народов используются после похорон два вида очищающих бань: паровая и водная. Не исключено, что скифы когда-то случайно начали использовать семена конопли в бане, пытаясь соединить два ритуала очищения (дымом и собственным потом) в одном. Что из этого получилось, красочно описал Геродот. Как видим, мало общего в обрядах очищения после похорон у тувинцев и скифов, но есть одна общая цель этих действий - тело должно очиститься после соприкосновения с ритуально нечистым телом умершего.

После похорон у тувинцев непосредственно следовала поминальная трапеза. Этот обряд универсален как для тюркоязычных, так и ираноязычных и других народов (Дьяконова, 1975: 59; Калоев, 1984: 90-91). В послепохоронный период у тувинцев поминальные ритуалы совершались на 7-е и 49-е сутки после смерти. Считалось, что в эти дни родственники общались с душой умершего при посредничестве шамана. Бытовало мнение, что на 49-е сутки умерший отделится от своего «светлого» мира и навсегда переселится в особый мир (Дьяконова, 1975: 59-66). Однако у большинства народов Евразии поминки умершего совершались на 9-й, 40-й дни и через год. Именно через год, по представлениям многих народов, душа умершего в последний раз возвращается в этот мир, чтобы навсегда вернуться в мир потусторонний. Вспомним пышные поминки, совершаемые через год на могиле скифского царя, что нашло описание у Геродота. По данным древнегреческого историка, по истечении года после похорон скифского царя совершалась поминальная тризна, которая сопровождалась жертвоприношениями людей и животных (50 юношей и 50 коней) (Иванчик, 2010: 144).

Таковыми являлись некоторые специфические черты погребальной обрядности тувинцев в XX в. Как видим, они оказались наиболее изученными и поэтому среди них можно выявить некоторые особенности, присущие кочевникам давних скифских времен. Следует отметить, что картина была бы более полной с привлечением данных современных полевых исследований. В данном случае можно говорить о перспективности данного направления исследований в будущем.

\section{Заключение}

Несмотря на то, что многое в погребальной обрядности тувинцев осталось достоянием прошлого, можно выделить зафиксированные этнографами некоторые черты похоронных обрядов тувинцев- 
шаманистов, которые находят параллели в традициях племён как скифского круга, так и народов, проживавших после скифов в Евразийской степи и на её границах. При этом нельзя отдельно рассматривать каждый погребальный обряд, а необходимо видеть всю похоронную церемонию как комплекс взаимосвязанных ритуальных действий.

Как оказалось, многие погребальные обряды тувинцев уходят корнями еще в доскифскую эпоху, но сама их последовательность совпадает с современными представлениями о похоронной церемонии кочевников скифской эпохи. Из таких совпадений следует выделить следующие элементы: ритуальное оплакивание умершего; доставка покойного на деревянных санях или верхом на лошади; захоронение умершего в скорченном положении на боку; под голову покойнику клали подушку; обсыпание умершего зернами проса; деревянные конструкции внутри могилы; захоронение коня; сооружение в недалеком прошлом кургана из камней; изготовление манекена или каменной стелы для изображения погребённого; после похорон поминальная трапеза и ритуальное очищение, и т. п.

Кроме того, в языческой похоронной церемонии тувинцев проявляются черты, которые находят соответствия в погребальных традициях древних гуннов и тюрок, аналогичных обрядам кочевников скифского времени. Это может означать, что к тувинцам эти традиции могли попасть через посредство древних хуннских и тюркских племен, которые являлись одними из потомков носителей скифской культуры в Центральной Азии.

Таким образом, мы видим, что с древнейших времен территория Тувы входила в ареал формирования общей идеологии кочевников, связанной с погребальным культом. Благодаря подвижности кочевников эти похоронные традиции очень быстро распространились на пространстве степей Евразии. Именно консервативность кочевого образа жизни могла способствовать тому, что многие древние погребальные традиции сохранились у тувинцев и их соседей.

\section{СПИСОК ЛИТЕРАТУРЫ}

Айыжы, Е. В. (2017) Погребально-поминальный обряд тувинцев Баян-Ульгийского и Хубсугульского аймаков Монголии // Новые исследования Тувы. № 1. С. 73-81. DOI: https:/www.doi.org/10.25178/nit.2017.1.5

Бесолова, Е. (2007) О ритуальном термине дугъ в погребальной обрядности осетин // 38. ICANAS 10-15/09/2007 Ankara/Türkiye. Bildiri őzetleri kitabi. Abstracts. Ankara. 1280 s. C. 93-94.

Бичурин, Н. Я. (Иакинф) (1950) Собрание сведений о народах, обитавших в Средней Азии в древние времена : в 3 т. М. ; Л. : АН СССР. Т. I. 342 с.

Бурнаков, В. А. (2009) К вопросу о похоронной обрядности у хакасов // Сибирский сборник-1: Погребальный обряд народов Сибири и сопредельных территорий: в 2-х кн. / отв. ред. Л. Р. Павлинская. СПб. : МАЭ РАН. Кн. 2. 226 с. С. $126-136$.

Вайнштейн, С. И. (1969) Происхождение и историческая этнография тувинского народа : дисс.... докт. ист. наук. M. 1247 c.

Вайнштейн, С. И. (1972) Историческая этнография тувинцев: проблемы кочевого хозяйства. М. : Наука. 312 с.

Вернадский, Г. (1934) Опыт истории Евразии: С половины VI века до настоящего времени. Берлин : Изд. Евразийцев. 189 с.

Вертієнко, Г. В. (2007) Принципи та моделі реконстроювання поховально-поминальної обрядовості іраномовних народів Євразійського степу [Принципы и модели реконструкции погребально-поминальной обрядности ираноязычных народов Евразийской степи] // Сходознавство [Востоковедение] / гол. ред. Л. В. Матвєєва [глав. ред. Л. В. Матвеева]. Київ : Інститут сходознавства НАНУ. № 39-40. 156 с. С. 3-23. (На укр. яз.)

Геродот (1972) История: в 9 кн. / пер. Г. А. Стратановского. Л. : Наука. 600 с.

Гиндин, Л. А., Шелов-Коведяев, Ф. В. (1994) Strava // Свод древнейших известий о славянах : в 2-х т. / отв. ред. Л. А. Гиндин, Г. Г. Литаврин. М. : Изд. фирм. «Восточная литература» РАН. Т. 1. 470 с. С. 161-169.

Грач, А. Д. (1980) Древние кочевники в центре Азии. М. : Наука. 257 с.

Грязнов, М. П. (1980) Аржан: царский курган раннескифского времени. Л. : Наука. 64 с.

Гумилев, Л. Н. (1989) Древняя Русь и Великая степь. М. : Мысль. 766 с.

Даржа, В. К. (2007) Тайны мировоззрения тувинцев-номадов. Кызыл : Правник. 255 с.

Дьяконова, В. П. (1966) О погребальном обряде тувинцев // Труды Тувинской комплексной археолого-этнографической экспедиции / отв. ред. Л. П. Потапов. М. ; Л. : Наука. Т. II. 364 с. С. 56-80.

Дьяконова, В. П. (1974) Отражение погребального обряда тувинцев в фольклоре // Фольклор и этнография: обряды и обрядовый фольклор / отв. ред. Б. Н. Путилов. Л. : Наука. 276 с. С. 259-265. 

$164 \mathrm{c}$.

Дьяконова, В. П. (1975) Погребальный обряд тувинцев как историко-этнографический источник. Л. : Наука.

Дьяконова, В. П. (1980) Тувинцы // Семейная обрядность народов Сибири: опыт сравнительного изучения / отв. ред. И. С. Гурвич. М. : Наука. 240 с. С. 113-119.

Дюмезиль, Ж. (1990) Скифы и нарты. М. : Наука. 288 с.

Евразия в скифскую эпоху: радиоуглеродная и археологическая хронология (2005) / науч. ред. Г. И. Зайцева и Н. А. Боковенко. СПб. : Теза. 290 с.

Зеленин, Д. К. (1991) Восточнославянская этнография. М. : Наука. 511 с.

Иванчик, А. И. (2010) Похороны скифских царей: Геродот и археология // Материалы и исследования по археологии России. М. : Таус. Т. 13. Археология и палеоантропология евразийских степей и сопредельных территорий / отв. ред. М. М. Герасимова, В. Ю. Малашев, М. Г. Мошкова. 496 с. С. 129-150.

Иордан (1960) О происхождении и деяних гетов: пер. с лат. Е. Ч. Скржинской. М.: Издательство восточной литературы. 436 с.

Калоев, Б. А. (1964) Обряд посвящения коня у осетин. Доклад. VII международный конгресс антропологических и этнографических наук (Москва, август 1964 г.). М. : Наука. 8 с.

Калоев, Б. А. (1984) Похоронные обычаи и обряды осетин в XVIII - начале XIX в. // Кавказский этнографический сборник / отв. ред. В. К. Гарданов. М. : Наука. Т. VIII. 280 с. С. 72-105.

Калоев, Б. А. (2004) Осетины: Историко-этнографическое исследование. М. : Наука. 471 с.

Катанов, Н. Ф. (1894) О погребальных обрядах у тюркских племен с древнейших времен до наших дней // Известия общества археологии, истории и этнографии при Казанском университете. Т. ХІІ. Вып. 2. С. $109-142$.

Каховский, В. Ф. (1965) Происхождение чувашского народа. Чебоксары : Чувашское книжное издательство. 262 с.

Кенин-Лопсан, М. Б. (1987) Обрядовая практика и фольклор тувинского шаманства. Конец XIX - начало XX в. Новосибирск : Наука. 164 с.

Кимеев, В. М. (2009) Погребальный обряд шорцев // Сибирский сборник-1: Погребальный обряд народов Сибири и сопредельных территорий: в 2-х кн. / отв. ред. Л. Р. Павлинская. СПб. : МАЭ РАН. Кн. 2. 226 с. С. $117-122$.

Кисель, В. А. (2009а) Нетюркские элементы погребального обряда тувинцев // Сибирский сборник-1: Погребальный обряд народов Сибири и сопредельных территорий: в 2-х кн. / отв. ред. Л. Р. Павлинская. СПб. : МАЭ РАН. Кн. 2. 226 с. С. 140-147.

Кисель, В. А. (2009b) Поездка за красной солью. Погребальные обряды Тувы. XVIII - начало XXI в. СПб. : Наука. 142 c.

Кисель, В. А. (2010) Современный похоронно-поминальный ритуал тувинцев [Электронный ресурс] // Новые исследования Тувы. № 4. С. 255-279. URL: https://nit.tuva.asia/nit/article/view/483 (дата обращения: 28.04.2020)

Ковалівський, А. (1995-1996) Зв’язки зі Сходом та сходознавство у Києві й Наддніпрянщині (передмова та публікація Валерія Рибалкіна) [Связи с Востоком и востоковедение в Киеве и Поднепровье (предисловие и публикация Валерия Рыбалкина] // Східний світ [Восточный мир]. № 2 (1995) - № 1 (1996). С. 146-167. (На укр. яз.).

Кон, Ф. Я. (1936) За пятьдесят лет. 2-е изд. М. : Советский писатель. 201 с.

Кореняко, В. А. (2002) Искусство народов Центральной Азии и звериный стиль. М. : Восточная литература. 327 с.

Кузьмина, Е. Е. (1977) Распространение коневодства и культа коня у ираноязычных племен Средней Азии и других народов Старого Света // Средняя Азия в древности и средневековье (история и культура) / под ред. Б. Г. Гафурова и Б. А. Литвинского. М. : Наука. 194 с. С. 28-52.

Курбатский, Г. Н. (2001) Тувинцы в своем фольклоре (историко-этнографические аспекты тувинского фольклора). Кызыл : Тувинское книжное издательство. 464 с.

Кызласов, Л. Р. (1969) История Тувы в средние века. М. : МГУ. 214 с.

Кызласов, Л. Р. (1979) Древняя Тува (от палеолита до IX в.). М. : МГУ. 208 с.

Маннай-оол, М. Х. (2004) Тувинцы: Происхождение и формирование этноса. Новосибирск : Наука. 166 с.

Маннай-оол, М. Х. (2010) Вклад Ф. Я. Кона в этнографическое изучение Тувы [Электронный ресурс] // Новые исследования Тувы. № 2. С. 135-142. URL: https:// https://nit.tuva.asia/nit/article/view/534 (дата обращения: 28.04.2020).

Мовсэс Каланкатуаци (1984) История страны Алуанк : пер. с др. арм. Ш. В. Смбатяна. Ереван : АН Ар. ССР. 258 с.

Молев, Е. А., Молева, Н. В. (2013) Скифские антропоморфные изваяния Северного Причерноморья: эмблемы власти и войны // Вестник Нижегородского университета им. Н. И. Лобачевского. № 4 (3). С. $15-21$.

Моця, А. П. (1987) Скорченные захоронения древнерусских некрополей // Древности Среднего Поднепровья / отв. ред. И. И. Артеменко. Киев : Наукова думка. 160 с. С. 101-105.

Окладников, А. П., Окладникова, Е. А., Запорожская, В. Д., Скорынина, Э. А. (1979) Петроглифы долины реки Елангаш (Юг Горного Алтая). Новосибирск : Наука. 136 с. 
Окладникова, Е. А. (1988) Волокуши индейцев равнин в этногенетическом и этноэкологическом аспектах // Экология американских индейцев и экскимосов: проблемы индеанистики / отв. ред. В. А. Тишков. М. : Наука. 338 с. С. 101-110.

Очир-Горяева, М. А. (2017) Сопровождающие погребения коней в скифских курганах Северного Причерноморья // Вестник Калмыцкого института гуманитарных исследований РАН. Т. 31. Вып. 3. C. 100-109. DOI: https:// www.doi.org/10.22162/2075-7794-2017-31-3-100-109

Очир-Горяева, М. А. (2019) Поза всадника по археологическим и этнографическим данным // Oriental studies. Вып. 5. С. 812-821. DOI: https://www.doi.org/10.22162/2619-0990-2019-45-5-812-821

Рапопорт, Ю. А. (1971) Из истории религии древнего Хорезма. М. : Наука. 124 с.

Руденко, С. И. (1953) Культура населения Горного Алтая в скифское время. М. ; Л. : АН СССР. 404 с.

Руденко, С. И. (1968) Древнейшие в мире художественные ковры и ткани из оледенелых курганов Горного Алтая. М. : Искусство. 136 с.

Савовський, І. П. (1977) Нові сарматські поховання на Запоріжжі [Новые сарматские погребения на Запорожье]// Археологія [Археология] / відп. ред. І. І. Артеменко. Київ : Наукова думка. Вип. 23. 100 с. С. 61-70.

Стручкова, А. В. (2016) Скифо-хуннские компоненты в ритуальных конструкциях и предметах бытового назначения из дерева у тюркоязычных народов Сибири // Вестник Томского государственного университета. № 408. C. 138-144. DOI: https://www.doi.org/10.17223/15617793/408/21

Трефильев, Е. П. (1905) Археологические экскурсии в Купянский уезд Харьковской губернии // Труды ХII Археологического съезда в Харькове, 1902: в 3-х т. / под ред. гр. Уваровой. М. : Товарищество типографии А. И. Мамонтова. Т. І. 427 с. С. 131-140.

Хазанов, А. М. (1975) Золото скифов. М. : Советский художник. 144 с.

Чугунов, К. В. (2009) Аржан-1 и Аржан-2: сравнительный анализ [Электронный ресурс] // Новые исследования Тувы. № 3. C. 176-186. URL: https:// https://nit.tuva.asia/nit/article/view/637 (дата обращения: 28.04.2020).

Чугунов, К. В., Парцингер, Г., Наглер, А. (2017) Царский курган скифского времени Аржан-2 в Туве. Новосибирск : Изд. ИАЭТ СО РАН. 500 с.

Шишло, Б. П. (1975) Среднеазиатский тул и его сибирские параллели // Домусульманские верования и обряды в Средней Азии / отв. ред. Г. П. Снесарев и В. Н. Басилов. М. : Наука. 344 с. С. 248-260.

Яковлев, Е. К. (1900) Этнографический обзор инородческого населения долины Южного Енисея и объяснительный каталог Этнографического отдела Музея. Минусинск : Изд. на средства В. А. Данилова. 357 с.

Bubenok, O. (2002) Iranian-Turkic Ethnic and Cultural Symbiosis in the Steppes of Turan after the Hunnic Expantion// Східний світ [Восточный мир]. № 1. Р. 86-89.

Bubenok, O. B. (2012) Funeral Ceremony of Ancient Turks as a Reflection of Contacts with Iranophone Nomads in the Sphere of Ideology // 38. ICANAS (International Congress of Asian and North African Studies). 10-15.09.2007. Ankara / Turkiye. Papers. History and History of Civilizations. Ankara : Atatürk Supreme Council for Culture, Language and History. Vol. II. 608 p. P. $745-754$.

Frobenius, L. (1909) The Childhood Of Man: A Popular Account Of The Lives, Customs And Thoughts Of The Primitive Races. London: Seeley \& Company Limited. 436 p.

Graebner, F. (1905) Kulturkreise und Kulturgeschichten in Ozeanien // Zeitschrift fr Ethnologie. Band 37. Berlin. S. 28-53.

Дата поступления: 28.10.2020 г.

\section{REFERENSES}

Aiyzhy, E. V. (2017) Pogrebal'no-pominal'nyi obriad tuvintsev Baian-Ul'giiskogo i Khubsugul'skogo aimakov Mongolii [The funeral and commemoration rite among the Tuvans of Bayan-Ölgii and Khövsgöl aimags, Mongolia]. New Research of Tuva, no. 1, pp. 73-81. (In Russ.). DOI: https://www.doi.org/10.25178/nit.2017.1.5

Besolova, E. (2007) O ritual'nom termine ‘dugъ' v pogrebal'noi obriadnosti osetin [On the ritual term Dug in the burial rituals of the Ossetians]. In: 38. ICANAS 10-15/09/2007, Ankara/Türkiye, Bildiri özetleri kitabi, Abstracts. Ankara. 1280 p. Pp. 93-94. (In Russ.).

Bichurin, N. Ya. (Iakinf) (1950) Sobranie svedenii o narodakh, obitavshikh v Srednei Azii v drevnie vremena [A collection of information about the peoples who lived in Central Asia in ancient times]: in 3 vols. Moscow, Leningrad, AN SSSR. Vol. I. 342 p. (In Russ.).

Burnakov, V. A. (2009) K voprosu o pokhoronnoi obriadnosti u khakasov [On funeral rituals among the Khakass]. In: Sibirskii sbornik-1: Pogrebal'nyi obriad narodov Sibiri i sopredel'nykh territorii [Siberian Collection-1: The Funeral Rite of the Peoples of Siberia and Neighboring Territories]: in 2 books / ed. L. P. Pavlinskaya. St. Peterburg, MAE RAN. Book 2. 226 p. Pp. 126-136. (In Russ.). 
Vainshtein, S.I.(1969) Proiskhozhdenie i istoricheskaia etnografiia tuvinskogo naroda [The origin and historical ethnography of the Tuvan people]: Diss.... Doctor of Historical Sciences. Moscow. 1247 p. (In Russ.).

Vainshtein, S. I. (1972) Istoricheskaia etnografiia tuvintsev. Problemy kochevogo khoziaistva [The historical ethnography of Tuvans. Problems of nomadic economy]. Moscow, Nauka. 314 p. (In Russ.).

Vernadsky, G. (1934) Opyt istorii Evrazii: S poloviny VI veka do nastoiashchego vremeni [Essay on the history of Eurasia: From mid-6 ${ }^{\text {th }}$ century to the present]. Berlin, Izd. Evraziitsev. 189 p. (In Russ.).

Vertiyenko, H. V. (2007) Pryntsypy ta modeli rekonstroyuvannya pokhoval'no-pomynal'noyi obryadovosti iranomovnykh narodiv Evraziys'koho stepu [Principles and models of reconstruction of funeral and memorial rites of Iranophone peoples of the Eurasian steppe]. In: Skhodoznavstvo [Oriental Studies] / ed. by L. V. Matveeva. Kyyiv, Instytut skhodoznavstva NANU. No. 39-40. 156 p. Pp. 3-23. (In Ukrainian).

Herodotus (1972) Istoriia $v$ deviati knigakh [The history, in nine books]. Transl. by G. A. Stratanovskiy. Leningrad, Nauka. 600 p. (In Russ.).

Gindin, L. A. and Shelov-Kovediaev, F. V. (1994) Strava. In: Svod drevneishikh izvestii o slavianakh [The collection of the oldest data about the Slavs]: in 2 vols. / ed. L. A. Gindin and G. G. Litavrin. Moscow, Vostochnaia literatura Publ. Vol. 1. 470 p. Pp. 161-169. (In Russ.).

Grach, A. D. (1980) Drevnie kochevniki v tsentre Azii [Ancient nomads in Central Asia]. Moscow, Nauka. 256 p. (In Russ.).

Griaznov, M. P.(1980) Arzhan: tsarskii kurgan ranneskifskogo vremeni [Arzhan: A royal mound of the Early Scythian time]. Leningrad, Nauka. 64 p. (In Russ.).

Gumilev, L. N. (1989) Drevniaia Rus' i Velikaia step' [Ancient Rus' and the Great Steppe]. Moscow, Mysl'. 766 p. (In Russ.).

Darzha, V. K. (2007) Tainy mirovozzreniia tuvintsev-nomadov [Secrets of the Tuvan nomads' worldview]. Kyzyl, Tuvan publishing house. 255 p. (In Russ.)

D'iakonova, V. P. (1966) O pogrebal'nom obriade tuvintsev [On the burial rite of the Tuvans]. In: Trudy Tuvinskoi kompleksnoi arkheologo-etnograficheskoi ekspeditsii [Proceedings of the Tuva Comprehensive Archaeological and Ethnographic Expedition] / ed. by L. P. Potapov. Moscow, Leningrad, Nauka. Vol. II. 364 p. Pp. 56-80. (In Russ.).

D'iakonova, V. P. (1974) Otrazhenie pogrebal'nogo obriada tuvintsev v fol'klore [Reflection of the Tuvan burial rite in folklore]. In: Fol'klor i etnografiia: obriady i obriadovyi fol'klor [Folklore and ethnography: rites and ritual folklore]. Ed. by B. N. Putilov. Leningrad, Nauka. Pp. 259-265. (In Russ.).

D'iakonova, V. P. (1975) Pogrebal'nyi obriad tuvintsev kak istoriko-etnograficheskii istochnik [Tuvan burial rite as a source for history and ethnography]. Leningrad, Nauka. 164 p. (In Russ.).

D'iakonova, V. P. (1980) Tuvintsy [Tuvans]. In: Semeinaia obriadnost' narodov Sibiri: opyt sravnitel'nogo izucheniia [Family rituals of the peoples of Siberia: a comparative study] / ed. By I. S. Gurvich. Moscow, Nauka. 240 p. Pp. 113-119. (In Russ.).

Dumézil, G. (1990) Skify i narty [The Scythians and Narts]. Moscow, Nauka. 288 p. (In Russ.).

Evraziia v skifskuiu epokhu: radiouglerodnaia i arkheologicheskaia khronologiia [Eurasia in the Scythian Era: Radiocarbon and Archaeological Chronology] (2005) / ed. G. I. Zaitsev and N. A. Bokovenko. St. Peterburg, Teza. 290 p. (In Russ.).

Zelenin D. K. (1991) Vostochnoslavianskaia etnografiia [East Slavic Ethnography]. Moscow, Nauka, 1991. 511 p. (In Russ.).

Ivanchik, A. I. (2010) Pokhorony skifskikh tsarei: Gerodot i arkheologiia [The funeral of the Scythian kings: Herodotus and archeology]. In: Materialy i issledovaniia po arkheologii Rossii [Materials and studies on archaeology of Russia]. Moscow, Taus. Vol. 13. Arkheologiia i paleoantropologiia evraziiskikh stepei i sopredel'nykh territorii. [Archeology and Paleoanthropology of the Eurasian Steppes and Neighboring Territories] / ed. M. M. Gerasimova. V. Yu. Malashev and M. G. Moshkova. 496 p. Pp. 129-150. (In Russ.).

Jordanes (1960) O proiskhozhdenii i deianikh getov [The origin and deeds of the Getae]. Transl. by E. Ch. Skrzhinskaya. Moscow, Publishing House of Oriental literature. 436 p. (In Russ.).

Kaloev, B. A. (1964) Obriad posviashcheniia konia u osetin. VII mezhdunarodnyi kongress antropologicheskikh $i$ etnograficheskikh nauk (Moskva, avgust 1964 g.) [The rite of consecration of a horse among the Ossetians [A paper given at] $7^{\text {th }}$ International Congress of Anthropological and Ethnographic Sciences (Moscow, August 1964)]. Moscow, Nauka. 8 p. (In Russ.).

Kaloev, B. A. (1984) Pokhoronnye obychai i obriady osetin v XVIII - nachale XIX vv. [Funeral customs and rituals of the Ossetians in the $18^{\text {th }}$ - early $19^{\text {th }}$ centuries]. In: Kavkazskii etnograficheskii sbornik [Caucasian Ethnographic Collection] / ed. by V. K. Gardanov. Moscow, Nauka. Vol. VIII. 280 p. Pp. 72-105. (In Russ.).

Kaloev, B. A. (2004) Osetiny: Istoriko-etnograficheskoe issledovanie [The Ossetians: A historical and ethnographic study]. Moscow, Nauka. 471 p. (In Russ.).

Katanov, N. F. (1894) O pogrebal'nykh obriadakh u tiurkskikh plemen s drevneishikh vremen do nashikh dnei [On burial rites among the Turkic tribes from ancient times to the present]. In: Izvestiia obshchestva arkheologii, istorii $i$ etnografii pri Kazanskom universitete [Proceedings of the Society of Archeology, History and Ethnography at Kazan' University]. Kazan'. Vol. XII. Issue 2. Pp. 109-142. (In Russ.). 
Kakhovskii, V. F. (1965) Proiskhozhdenie chuvashskogo naroda [The origin of the Chuvash people]. Cheboksary, Chuvash Book Publishing House. 262 p. (In Russ.).

Kenin-Lopsan, M. B. (1987) Obriadovaia praktika i fol'klor tuvinskogo shamanstva. Konets XIX - nachalo XX v. [Ritual practice and folklore of Tuvinian shamanism: Late XIX - early XX century]. Novosibirsk, Nauka. 165 p. (In Russ.).

Kimeev, V. M. (2009) Pogrebal'nyi obriad shortsev [Funeral Rite of the Shorts People]. In: Sibirskii sbornik-1: Pogrebal'nyi obriad narodov Sibiri i sopredel'nykh territorii [Siberian Collection-1: The Funeral Rite of the Peoples of Siberia and Neighboring Territories]: in 2 books / ed. by L. R. Pavlinskaia. St. Peterburg, MAE RAN. Book 2. 226 p. Pp. 117-122. (In Russ.).

Kisel', V. A. (2009a) Netiurkskie elementy pogrebal'nogo obriada tuvintsev [Non-Turkic elements in Tuvan burial rite]. In: Sibirskii sbornik-1: Pogrebal'nyi obriad narodov Sibiri i sopredel'nykh territorii: $v$ 2-kh knigakh [Siberian Collection-1: The Funeral Rite of the Peoples of Siberia and Neighboring Territories: in 2 books] / ed. by L. R. Pavlinskaia. St. Peterburg, MAE RAN. Book 2. 226 p. Pp. 140-147. (In Russ.).

Kisel', V. A. (2009b) Poezdka za krasnoi sol'iu. Pogrebal'nye obriady Tuvy. XVIII - nachalo XXI v. [A journey for the red salt. Funeral rites of Tuva: XVIII - early XXI century]. St. Petersburg, Kunstkamera. 142 p. (In Russ.).

Kisel', V. A. (2010) Sovremennyi pokhoronno-pominal'nyi ritual tuvintsev [Contemporary funeral and commemoration ceremony of Tuvans]. New Research of Tuva, no. 4, pp. 255-279 [on-line] Available at: https://nit.tuva.asia/nit/article/ view/483 (access date: 28.04.2020). (In Russ.).

Kovalivs'kyy, A. (1995-1996) Zv’yazky zi Skhodom ta skhodoznavstvo u Kyyevi y Naddnipryanshchyni (peredmova ta publikatsiya Valeriya Rybalkina) [Relations with the Orient and Oriental studies in Kyiv and the Dnieper region: preface and publication by Valery Rybalkin)] In: Skhidnyy svit [The World of the Orient], no. 2 (1995) - no. 1 (1996). Pp. $146-167$. (In Ukrainian).

Kon, F. Ya. (1936) Za piat'desiat let [In fifty years]. $2^{\text {nd }}$ ed. Vol. 3-4. Moscow, Sovetskii Pisatel' Publ. 344 p. (In Russ.).

Koreniako, V. A. (2002) Iskusstvo narodov Tsentral'noi Azii i zverinyi stil' [Art of the Peoples of Central Asia and the Animal Style]. Moscow, Vostochnaia literatura. 327 p. (In Russ.).

Kuz'mina, E. E. (1977) Rasprostraneniei konevodstva i kul'ta konia u iranoiazychnykh plemen Srednei Azii i drugikh narodov Starogo Sveta [The rise of horse breeding and the cult of the horse among the Iranophone tribes of Central Asia and other peoples of the Old World]. In: Sredniaia Aziia v drevnosti i srednevekov'e (istoriia $i$ kul'tura) [Central Asia in the Antiquity and the Middle Ages: History and culture] / ed. by B. G. Gafurov and B. A. Litvinskiy. Moscow, Nauka. 194 p. Pp. 28-52. (In Russ.).

Kurbatskii, G. N. (2001) Tuvintsy $v$ svoem fol'klore (istoriko-etnograficheskie aspekty tuvinskogo fol'klora) [Tuvans in their folklore: Historical and ethnographic aspects of Tuvan folklore)]. Kyzyl, Tuva book publishing house. 464 p. (In Russ.).

Kyzlasov, L. R. (1969) Istoriia Tuvy v srednie veka [The History of Tuva in the Middle Ages]. Moscow, MGU Publ. 214 p. (In Russ.).

Kyzlasov, L. R. (1979) Drevniaia Tuva (ot paleolita do IX v.) [Ancient Tuva, from the Paleolithic to the 9th century]. Moscow, MGU. 208 p. (In Russ.).

Mannai-ool, M. Kh. (2004) Tuvintsy: proiskhozhdenie i formirovanie tuvinskogo etnosa [Tuvans: the origin and formation of the Tuvan ethnos]. Novosibirsk, Nauka. 166 p. (In Russ.).

Mannai-ool, M. Kh. (2010) Vklad F. Ya. Kona v etnograficheskoe izuchenie Tuvy [F. Ya. Kon's contribution to the ethnographic study of Tuva]. New Research of Tuva, no. 2, pp. 135-142 [on-line] Available at. https:// https://nit.tuva.asia/ nit/article/view/534 (access date: 28.04.2020). (In Russ.).

Movses Kalankatuatsi (1984) Istoriia strany Aluank [A History of [Caucasian] Albania].Transl. by Sh. V. Smbatian. Erevan, AN Ar. SSR. 258 p. (In Russ.).

Molev, E. A. and Moleva, N. V. (2013) Skifskie antropomorfnye izvaianiia Severnogo Prichernomor'ia: emblemy vlasti i voiny [Scythian anthropomorphic sculptures of the Northern Black Sea region: Emblems of power and war]. Vestnik of Lobachevsky University of Nizhni Novgorod, no. (3), pp. 15-21. (In Russ.).

Motsia, A. P. (1987) Skorchennye zakhoroneniia drevnerusskikh nekropolei [Crumpled burials at the necropolises of Old Rus']. In: Drevnosti Srednego Podneprov'ia [Antiquities of the Middle Dnieper basin] / ed. by I. I. Artemenko. Kiev, Naukova dumka. 160 p. Pp. 101-105. (In Russ.).

Okladnikov, A. P., Okladnikova, E. A., Zaporozhskaia, V. D. and Skorynina, E. A. (1979) Petroglify doliny reki Elangash (Iug Gornogo Altaia) [Petroglyphs of the Elangash River valley in the South Altai]. Novosibirsk, Nauka. 136 p. (In Russ.).

Okladnikova, E. A. (1988) Volokushi indeitsev ravnin v etnogeneticheskom i etnoekologicheskom aspektakh [Sleds in use of indigenous people of the American plains in the ethnogenetic and ethnoecological aspects]. In: Ekologiia amerikanskikh indeitsev i ekskimosov: problemy indeanistiki [Ecology of the indigenous American peoples and the Inuit: issues of indigenous studies] / ed. by V. A. Tishkov. Moscow, Nauka. 338 p. Pp. 101-110. (In Russ.). 
Ochir-Goryaeva, M. A. (2017) Soprovozhdaiushchie pogrebeniia konei v skifskikh kurganakh Severnogo Prichernomor'ia [Accompanying horse burials in Scythian mounds of the Northern Black Sea region]. Vestnik Kalmytskogo instituta gumanitarnykh issledovanii RAN [Bulletin of the Kalmyk Institute for Humanities of the Russian Academy of Sciences], vol. 31, issue 3, pp. 100-109. (In Russ.). DOI: https://doi.org/10.22162/2075-7794-2017-31-3-100-109

Ochir-Goryaeva, M. A. (2019) Poza vsadnika po arkheologicheskim i etnograficheskim dannym [Body postures of buried horsemen: Archaeological and ethnographic evidence]. Oriental Studies, issue 12(5), pp. 812-821. (In Russ.). DOI: https:// doi.org/10.22162/2619-0990-2019-5-812-821

Rapoport, Yu. A. (1971) Iz istorii religii drevnego Khorezma [From the history of religion in ancient Khorezm]. Moscow, Nauka. 124 p. (In Russ.).

Rudenko, S. I. (1953) Kul'tura naseleniia Gornogo Altaia v skifskoe vremia [The Culture of the Population of the Gorny Altai in the Scythian Times]. Moscow, Leningrad, AN SSSR. 404 p. (In Russ.).

Rudenko, S. I. (1968) Drevneishie v mire khudozhestvennye kovry i tkani iz oledenelykh kurganov Gornogo Altaia [The Oldest Carpets and Textiles from the Frozen Mounds of the Altai]. Moscow, Iskusstvo. 136 p. (In Russ.).

Savovs'kyy, I. P. (1977) Novi sarmats'ki pokhovannya na Zaporizhzhi [New Sarmatian Burials in Zaporizhzhe Region]. In: Arkheolopya [Archaeology] / ed. by I. I. Artemenko. Kyyiv, Nakova dumka. Issue 23. 100 p. Pp. 61-70. (In Russ.).

Struchkova, A. V. (2016) Skifo-khunnskie komponenty v ritual'nykh konstruktsiiakh i predmetakh bytovogo naznacheniia iz dereva u tiurkoiazychnykh narodov Sibiri [Scythian-Hunnic components of ritual structures and domestic items made of wood of the Turkic-speaking peoples of Siberia]. Tomsk State University Journal, no. 408, pp. 138-144. (In Russ.). DOI: https://www.doi.org/10.17223/15617793/408/21

Trefil'ev, E. P. (1905) Arkheologicheskie ekskursii v Kupianskii uezd Khar'kovskoi gubernii [Archaeological Excursions to the Kupyansk Uezd of Kharkiv Governorate]. In: Trudy XII Arkheologicheskogo S'ezda v Khar'kove, 1902 [Proceedings of the $12^{\text {th }}$ Archaeological Congress in Kharkov, 1902]: in 3 vols. / ed. by Countess Uvarova. Moscow, Tovarishchestvo tipografii A. I. Mamontova. Vol. I. 427 p. Pp. 131-140. (In Russ.).

Khazanov, A. M. (1975) Zoloto skifov [Scythian Gold]. Moscow, Sovetskii khudozhnik. 144 p. (In Russ.).

Chugunov, K. V. (2009) Arzhan-1 i Arzhan-2: sravnitel'nyi analiz [Arzhan I and Arzhan II: a comparative Analysis]. New Research of Tuva, no. 3, pp. 176-186 [on-line] Available at: https://nit.tuva.asia/nit/article/view/637 (access date: 28.04.2020). (In Russ.).

Chugunov, K. V., Partsinger, G. and Nagler, A. (2017) Tsarskii kurgan skifskogo vremeni Arzhan-2 v Tuve [Arzhan II, the royal mound of the Scythian times in Tuva.]. Novosibirsk, Izd. IAET SO RAN. 500 p. (In Russ.).

Shishlo, B. P. (1975) Sredneaziatskii tul i ego sibirskie paralleli In: Domusul'manskie verovaniia i obriady v Srednei Azii [Central Asian Tul and its Siberian Parallels] / ed. by G. P. Snesarev and V. N. Basilov. Moscow, Nauka. 344 p. Pp. $248-260$. (In Russ.).

Yakovlev, E. K. (1900) Etnograficheskii obzor inorodcheskogo naseleniya doliny Yuzhnogo Eniseya i ob;yasnitel'nyi katalog Etnograficheskogo otdela Muzeya [An ethnographic review of the South Yenisei Valley and the explanatory catalogue of the Museum's Ethnography Research Department]. Minusinsk, V. I. Kornakov. 357 p. (In Russ.).

Bubenok, O. (2002) Iranian-Turkic Ethnic and Cultural Symbiosis in the Steppes of Turan after the Hunnic Expantion. Skhidnyy svit [The World of the Orient], no. 1, pp. 86-89.

Bubenok, O. B. (2012) Funeral Ceremony of Ancient Turks as a Reflection of Contacts with Iranophone Nomads in the Sphere of Ideology. In: 38. ICANAS (International Congress of Asian and North African Studies). 10-15.09.2007. Ankara / Turkiye. Papers, History and History of Civilizations. Ankara, Atatürk Supreme Council for Culture, Language and History. Vol. II. 608 p. Pp. $745-754$.

Frobenius, L. (1909) The Childhood Of Man: A Popular Account Of The Lives, Customs And Thoughts Of The Primitive Races. London, Seeley \& Company Limited. 436 p.

Graebner, F. (1905) Kulturkreise und Kulturgeschichten in Ozeanien. Zeitschrift fr Ethnologie. Band 37. Berlin. S. $28-53$. Submission date: 28.10 .2020 . 